A N N A LE S

UNIVER S T A T IS MARIAE CURIE-SKŁODOW S A LUBLIN - POLONIA

VOL. XXVIII, 2

SECTIO J

2015

Uniwersytet Pedagogiczny im. Komisji Edukacji Narodowej w Krakowie

\title{
KATARZYNA TOMASZEK
}

kat.tomaszek@gmail.com

\section{Obraz siebie u młodzieży wyalienowanej}

The Relationship between Self Concept and Student Alienation

\section{STRESZCZENIE}

Celem artykułu jest określenie specyficznych cech obrazu siebie młodzieży wyalienowanej. Analizy teoretyczne i empiryczne wskazują, że doświadczanie wyalienowania przez młodzież wiąże się z poważnymi zniekształceniami w percepcji siebie w kierunku nadmiernej krytyki siebie, braku akceptacji siebie, mniejszej zwartości struktury obrazu siebie oraz obecności tendencji sprzecznych w percepcji siebie, jak również skłonności do zafałszowywania opisu własnej osoby. Ponadto badania ujawniły obecność u młodzieży wyalienowanej zaburzeń w zakresie koncepcji siebie, szczególnie wzmożonej obronności, wysokiego ogólnego nieprzystosowania, obecności defektów i nieprawidłowości osobowości oraz silnej tendencji do zachowań neurotycznych. Wyniki przeprowadzonej krokowej regresji wielokrotnej wskazują, że na całkowity poziom ogólnego wyobcowania w badanej grupie nastolatków wpływ ma wynik ogólny obrazu siebie (WO) i neurotyzm (N). Współczynnik wielokrotnej determinacji $\left(\mathrm{R}^{2}=0,465\right)$ wskazuje na to, że $46 \%$ wariancji wyników ogólnego poziomu wyalienowania może być wyjaśniane za pomocą wyodrębnionych zmiennych psychologicznych.

Słowa kluczowe: poczucie alienacji; adolescencja; obraz siebie; zaburzenia koncepcji siebie

\section{WPROWADZENIE}

Psycholodzy wśród najważniejszych zadań rozwojowych okresu adolescencji wymieniają formowanie się tożsamości (Brzezińska 2006). Proces ten dokonuje się na drodze nabywania nowych doświadczeń, poszukiwania nowych kie- 
runków zainteresowań, ale również przez negację obowiązujących reguł i kwestionowanie autorytetów. Kryzysom pojawiającym się w okresie dorastania towarzyszy silne poczucie zagubienia i dezorientacji odnośnie do własnych przeżyć i zachowań. Jak zauważa Z. Chlewiński (2000, s. 112), „kryzysy młodego wieku mogą pozostawić bardzo silne rysy w osobowości człowieka. Niosą bowiem ze sobą niebezpieczeństwo pojawienia się zniekształceń w rozwoju osobowości prowadzące do ukształtowania się osobowości niedojrzałej, neurotycznej, egocentrycznej”. Zdaniem P. Zawadzkiego (2007) wielu młodych ludzi nie nadąża za narzuconym szybkim tempem życia, czego konsekwencją może być alienacja przejawiająca się wycofaniem z życia społecznego oraz postawą rezygnacji z planów, marzeń, pragnień i zainteresowań. W dalszej perspektywie pojawić się może głęboka frustracja egzystencjalna, uniemożliwiająca młodemu człowiekowi konstruktywne funkcjonowanie w społeczeństwie już w życiu dorosłym.

Próby poradzenia sobie $\mathrm{z}$ własną alienacją $\mathrm{w}$ wieku młodzieńczym najczęściej polegają na internalizacji problemów (co generuje zaburzenia emocjonalne) lub ich manifestowaniu przez zachowania buntownicze i ryzykowne (tj. nadużywanie alkoholu, środków psychoaktywnych) (Windle, Davies 2003; Cierpiałkowska 2006; Chodkiewicz, Śmiałkowska 2007). Pozytywnemu przezwyciężeniu wątpliwości i niepokojów okresu dorastania sprzyja posiadanie źródeł wsparcia w postaci bliskich relacji z rodziną, rówieśnikami czy nauczycielami (Tomaszek, Tucholska 2012). Badania M. Biegasiewicz (2010) wskazują, że poczucie alienacji wiąże się u nieletnich $\mathrm{z}$ brakiem otrzymywania wsparcia informacyjnego, materialnego oraz negatywnymi komunikatami od rodziców, rodziny, kolegów. Brak akceptacji przez środowisko rodzinne i szkolne wybranych przez nastolatka wartości i celów życiowych stanowi barierę blokującą jego rozwój (Woźniak-Krakowian, Ortenburger 2003).

Referowane badania empiryczne zostały przeprowadzone na grupie młodzieży w latach 2009-2010, a ich podstawą było systemowe podejście do poczucia alienacji zaproponowane przez M. Seemana $(1959,1975)$, dopracowane przez K. Kmiecik-Baran (1995). Autorzy ci traktują zjawisko wyalienowania jako „przekonanie jednostki, że pewne obszary świata są obce, nie pozwalają na realizację jej potrzeb. Doświadczenie obcości może dotyczyć: norm społecznych; wartości; innych ludzi; siebie, a więc tego, co jednostka robi czy głosi, jeśli czyniąc to, czuje się do takich zachowań zmuszona" (Kmiecik-Baran 1995, s. 28). Alienacja jest tu traktowana jako jeden z krańców kontinuum. Jednostka, która nie doświadcza wyalienowania, cechuje się poczuciem zakorzenienia czy integracji. Seeman $(1959,1975)$ wyodrębnił pięć wymiarów poczucia alienacji: poczucie anomii, poczucie bezsensu, poczucie bezradności, poczucie samowyobcowania, poczucie izolacji (osamotnienia). 


\section{CEL PRACY I HIPOTEZY BADAWCZE}

W artykule przedstawiono wyniki badań empirycznych uzyskane w ramach szerszego programu badawczego pt. „Podmiotowe uwarunkowania poczucia alienacji u młodzieży" (Tomaszek 2010). Celem przeprowadzonych analiz jest ustalenie specyficznych cech obrazu siebie u młodzieży wyalienowanej. Na bazie istniejących koncepcji teoretycznych dotyczących poczucia alienacji oraz wyników badań naukowych postawiono trzy hipotezy badawcze:

H1. Młodzież wyalienowana odznacza się zniekształconym obrazem siebie $\mathrm{z}$ nasiloną tendencją do deprecjonowania i odrzucania własnej osoby.

H2. Obraz siebie młodzieży wyobcowanej cechuje się niską zwartością i obecnością sprzecznych tendencji.

H3. Istnieje specyficzna konstelacja cech obrazu siebie związana z doświadczaniem poczucia alienacji przez młodzież.

\section{METODY I PROCEDURA BADANIA}

W celu zweryfikowania postawionej hipotezy badawczej do pomiaru zmiennych wykorzystano następujące narzędzia badawcze:

1 Skala Poczucia Alienacji (SPA) Kmiecik-Baran (1995) - składa się ze 100 itemów, na które badani odpowiadają na pięciostopniowej skali. Autorka opracowała normy dla młodzieży (uczniowie trzeciej klasy liceum) oraz osób mających konflikt z prawem. Skala umożliwia obliczenie Ogólnego Poziomu Poczucia Alienacji (WOPA), jak również wyniku dla każdego z pięciu wymiarów poczucia alienacji, takich jak: poczucie anomii (PA), poczucie bezsensu (PS), poczucie bezradności (PB), poczucie samowyobcowania (PSW), poczucie osamotnienia (PO). Właściwości psychometryczne skali: rzetelność dla całej skali wynosi $\mathrm{rtt}=0,88$; dla poczucia anomii, bezsensu, bezradności i osamotnienia: $\mathrm{rtt}=0,94-0,98$; dla poczucia samowyobcowania: $\mathrm{rtt}=0,28$.

2 Kwestionariusz do badania obrazu siebie (TSCS) Fittsa - składa się ze 100 stwierdzeń, przy pomocy których osoba odpowiadająca dokonuje opisu siebie na pięciostopniowej skali. Skalę można wykorzystać zarówno do badań indywidualnych, jak i grupowych osób powyżej 12. roku życia. W badaniu wykorzystano wersję kliniczno-badawczą, która składa się z 29 skal (Fitts 1965, 1988, za: Uchnast 2007). Autor metody wyróżnia kilka podstawowych czynników wpływających na sposób percepcji siebie, opis własnej osoby oraz zniekształcenia w koncepcji siebie (Steuden 1997). Skala umożliwia ocenę 29 wskaźników obrazu siebie pogrupowanych w wymiary. Są to: 1) Samokrytycyzm (SK), 2) Wynik ogólny pozytywny (WO) - to suma wyników uzyskanych w wymia- 
rach wewnętrznych (wyróżnia się tu skale: TO - tożsamość, ZS - zadowolenie z siebie, $\mathrm{Z}$ - zachowanie) i zewnętrznych (wyróżnia się tu skale: SF - ,ja" fizyczne, SM - ,ja" moralno-etyczne, SO - ,ja" osobiste, SR - ,ja” rodzinne, SS - ,ja” społeczne); 3) Zmienność wymiarów obrazu siebie (ZW) - określenie wysokości ZW jest dokonywane na bazie takich wskaźników, jak: ZWO - Całkowita zmienność obrazu siebie, ZWZ - Zmienność wymiarów zewnętrznych, ZWW - Zmienność wymiarów wewnętrznych; 4) Rozkład odpowiedzi (RO) - wskaźnik preferencji wyboru określonej odpowiedzi na pięciostopniowej skali, stąd RO1, RO2, RO3, RO4, RO5; 5) Stosunek odpowiedzi prawdziwych do fatszywych (T/F); 6) Skala Konfliktów - tworzą ją dwa wymiary: Konflikt sieciowy (NetConf) i Konflikt całkowity (NetTot); 7) Skale Empiryczne - wyróżnia się tu takie skale, jak: Pozytywna samoobrona (DP), Ogólne nieprzystosowanie (GM), Psychotyzm (PSY), Zaburzenia osobowości (PD), Neurotyzm (N), Integracja osobowości (PI), Wskaźnik symptomów patologicznych (wskaźnik zaburzeń) (NDS). Właściwości psychometryczne kwestionariusza TSCS: Rzetelność testu dla obu wersji jest wysoka i wynosi od .60 (Tot Var) do .92 (Tot Poz i Psy) (Uchnast 2007).

Badania przeprowadzono na przełomie 2009 i 2010 r. w liceach ogólnokształcących i plastycznych. Dobór grupy badanej młodzieży był podyktowany dotychczasowymi ustaleniami takich autorów, jak: E.H. Erikson (2002), B.M. Newman i P.R. Newman (2001) oraz A. Giddens (2001). Autorzy ci uznają okres adolescencji jako czas zmagania się z kryzysem dotyczącym zdefiniowania siebie przez pryzmat relacji z otoczeniem. Funkcjonują tu takie określenia, jak: tożsamość vs rozproszenie oraz intymność vs izolacja (Erikson 2002), identyfikacja z grupą vs alienacja od otoczenia (Newman, Newman 2001) oraz nawiązujące do koncepcji alienacji E. Fromma doświadczenia osobiste vs doświadczenia urynkowione (Giddens 2001).

W badaniach wzięło udział 508 uczniów. Z uwagi na niekompletność wypełnionych kwestionariuszy $\mathrm{w}$ dalszych analizach statystycznych uwzględniono wyniki 331 osób, w tym 212 kobiet i 119 mężczyzn. Wiek osób badanych wahał się od 16 do 20 roku życia.

Zadaniem osób badanych było wypełnienie zestawu różnych metod psychologicznych. Czas wypełniania pojedynczego zestawu wynosił około 60 minut.

\section{WYNIKI}

W ramach opracowania wyników wykorzystano takie analizy statystyczne, jak: statystyki opisowe (średnie i odchylenia standardowe), analiza skupień metodą $k$ średnich, test korelacji dwustronnej Pearsona, analiza wielokrotnej regresji krokowej. W celu ukazania różnic między poziomem doświadczanego wyobco- 
wania $\mathrm{w}$ grupie badanej młodzieży posłużono się analizą skupień metodą $k$ średnich na wynikach Skali Poczucia Alienacji Kmiecik-Baran. Wyniki tej analizy zamieszczone zostały w tab. 1.

Zastosowana analiza skupień pozwoliła na wyłonienie trzech grup nastolatków różniących się stopniem wyalienowania. Pierwszą grupę tworzą nastolatki charakteryzujące się wysokimi i podwyższonymi wynikami w odniesieniu do wszystkich skal mierzących wyobcowanie (Młodzież Oderwana). Kolejną grupę tworzą badani, którzy uzyskali najniższe wskaźniki wyobcowania (Młodzież Dostosowana). Trzecią grupę tworzy młodzież, która w największym stopniu doświadcza anomii i osamotnienia (Młodzież Wyizolowana).

Tab. 1. Charakterystyka poziomu wyalienowania w badanej grupie młodzieży

\begin{tabular}{|l|c|c|c|c|c|c|}
\hline & \multicolumn{2}{|c|}{$\begin{array}{c}\text { Gr. 1. Wyizolowani } \\
\mathrm{N}=85\end{array}$} & \multicolumn{2}{c|}{$\begin{array}{c}\text { Gr. 2. Dostosowani } \\
\mathrm{N}=139(42 \%)\end{array}$} & \multicolumn{2}{c|}{$\begin{array}{c}\text { Gr. 3. Oderwani } \\
\mathrm{N}=107(32 \%)\end{array}$} \\
\cline { 2 - 8 } & $\mathrm{M}$ & $\sigma$ & $\mathrm{M}$ & $\sigma$ & $\mathrm{M}$ & $\sigma$ \\
\hline $\begin{array}{l}\text { WOA - ogólny poziom } \\
\text { poczucia alienacji }\end{array}$ & 5,36 & 1,33 & 4,06 & 1,42 & 7,49 & 1,17 \\
\hline PA - poczucie anomii & 6,44 & 1,52 & 3,83 & 1,67 & 6,04 & 1,62 \\
\hline PS - poczucie bezsensu & 5,87 & 1,84 & 4,12 & 1,36 & 7,09 & 1,42 \\
\hline PB - poczucie bezradności & 4,28 & 1,68 & 5,04 & 1,62 & 7,40 & 1,32 \\
\hline $\begin{array}{l}\text { PSA - poczucie } \\
\text { samowyobcowania }\end{array}$ & 3,72 & 1,50 & 5,42 & 1,65 & 6,96 & 1,47 \\
\hline PO - poczucie osamotnienia & 6,42 & 1,49 & 4,14 & 1,52 & 6,66 & 1,67 \\
\hline
\end{tabular}

Źródło: K. Tomaszek (2010), Podmiotowe uwarunkowania poczucia alienacji u młodzieży, Lublin: Archiwum KUL (niepublikowana rozprawa doktorska), s. 301.

W kontekście postawionych hipotez badawczych ważne staje się ukazanie różnic w zakresie obrazu siebie pomiędzy wyłonionymi grupami.

Tab. 2. Różnice między poczuciem alienacji w wyłonionych grupach a ogólną samooceną oraz wymiarami wewnętrznymi i zewnętrznymi obrazu siebie (Test Kruskala-Willysa)

\begin{tabular}{|c|c|c|c|c|c|c|c|c|c|c|}
\hline Zmienna & SK & WO & TO & ZS & ZA & SF & SM & SO & SR & SS \\
\hline$\chi^{2}$ & 16,462 & 120,880 & 109,316 & 83,128 & 105,244 & 61,803 & 73,306 & 89,345 & 94,727 & 62,657 \\
\hline P & 0,000 & 0,000 & 0,000 & 0,000 & 0,000 & 0,000 & 0,000 & 0,000 & 0,000 & 0,000 \\
\hline Df & 2 & 2 & 2 & 2 & 2 & 2 & 2 & 2 & 2 & 2 \\
\hline
\end{tabular}

Źródło: opracowanie na podstawie badań własnych.

W sprofilowanych pod kątem poziomu wyalienowania skupieniach odnotowano istotne statystycznie różnice w odniesieniu do: Samokrytycyzmu (SK); 
Ogólnego poziomu samooceny; wszystkich wymiarów wewnętrznych i zewnętrznych obrazu siebie, takich jak: Tożsamość (TO), Zadowolenie z siebie (ZS), Zachowanie (ZA), ,ja" fizyczne (SF), ,ja" moralne (SM), ,ja" osobiste (SO), ,ja" rodzinne (SR), ,ja" społeczne (SS).

Tab. 3. Różnice między poczuciem alienacji w wyłonionych grupach a skalami empirycznymi obrazu siebie (Test Kruskala-Willysa)

\begin{tabular}{|c|c|c|c|c|c|c|}
\hline Zmienna & DP & GM & PSY & PD & N & PI \\
\hline$\chi^{2}$ & 81,114 & 101,658 & 11,626 & 90,675 & 116,650 & 12,398 \\
\hline P & 0,000 & 0,000 & 0,003 & 0,000 & 0,000 & 0,002 \\
\hline Df & 2 & 2 & 2 & 2 & 2 & 2 \\
\hline
\end{tabular}

Źródło: opracowanie na podstawie badań własnych.

Wszystkie skale empiryczne różnicowały na poziomie istotnym wyłonione grupy, tj. Pozytywna samoobrona (DP), Ogólne nieprzystosowanie (GM), Psychotyzm (PSY), Zaburzenia osobowości (PD), Neurotyzm (N), Integracja osobowości (PI).

Tab. 4. Różnice między poczuciem alienacji w wyłonionych grupach a skalami konfliktu, rozkładem odpowiedzi i zmiennością obrazu siebie (Test Kruskala-Willysa)

\begin{tabular}{|c|c|c|c|c|c|c|}
\hline Zmienna & Zwo & ZWZ & ZWW & RO & C.net. & C.tot. \\
\hline$\chi^{2}$ & 0,688 & 4,187 & 8,780 & 31,216 & 0,256 & 0,139 \\
\hline $\mathrm{P}$ & 0,847 & 0,270 & 0,012 & 0,000 & 0,077 & 0,456 \\
\hline Df & 3 & 2 & 2 & 2 & 2 & 2 \\
\hline
\end{tabular}

Źródło: opracowanie na podstawie badań własnych.

Istotne różnice odnotowano również w zakresie zmienności wymiarów wewnętrznych (ZWW) oraz rozkładu odpowiedzi (RO). Wskaźniki obrazu siebie - tj. skale konfliktu: Konflikt sieciowy (C.net.) i Konflikt totalny (C.tot.), Całkowita zmienność obrazu siebie (ZWO) oraz Zmienność wymiarów zewnętrznych (ZWZ) - nie różnicowały wyłonionych grup.

Powyższe wyniki potwierdzają, że młodzież o zróżnicowanym poziomie wyobcowania różni się w zakresie większości wymiarów obrazu siebie. W celu określenia kierunku i siły związku między poczuciem alienacji a obrazem siebie przeprowadzono analizę korelacyjną. Obliczone współczynniki korelacji $r$ Pearsona dla całości grupy zawiera tab. 5 . W analizach nie uwzględniono płci osób badanych, gdyż w większości przypadków różnice między kobietami a mężczyznami dotyczyły tylko siły związku. W tabeli pominięto także korelacje nieistotne statystycznie. 
Tab. 5. Macierz korelacji dwustronnych istotnych statystycznie $(\mathrm{p} \leq 0,001)$ (nie uwzględniono korelacji nieistotnych statystycznie)

\begin{tabular}{|c|c|c|c|c|c|c|}
\hline $\begin{array}{c}\text { Zmienne } \\
\text { badające } \\
\text { obraz siebie }\end{array}$ & $\begin{array}{c}\text { WOPA - } \\
\text { ogólny po- } \\
\text { ziom poczu- } \\
\text { cia alienacji }\end{array}$ & $\begin{array}{l}\text { PA - poczu- } \\
\text { cie anomii }\end{array}$ & $\begin{array}{l}\text { PS - poczu- } \\
\text { cie bezsensu }\end{array}$ & $\begin{array}{l}\text { PB - poczu- } \\
\text { cie bezrad- } \\
\text { ności }\end{array}$ & $\begin{array}{l}\text { PSA - po- } \\
\text { czucie sa- } \\
\text { mowyobco- } \\
\text { wania }\end{array}$ & $\begin{array}{l}\mathrm{PO} \text { - poczu- } \\
\text { cie osamot- } \\
\text { nienia }\end{array}$ \\
\hline SK &, $242 * * *$ &, $325 * * *$ &, $265 * * *$ & & & \\
\hline WO &,$- 672 * * *$ &,$- 332 * * *$ &,$- 597 * * *$ &,$- 490 * * *$ &,$- 322 * * *$ &,$- 437 * * *$ \\
\hline $\mathrm{TO}$ &,$- 603 * * *$ &,$- 305 * * *$ &,$- 606 * * *$ &,$- 390 * * *$ &,$- 197 * * *$ &,$- 461 * * *$ \\
\hline $\mathrm{ZS}$ &,$- 571 * * *$ &,$- 213 * * *$ &,$- 430 * * *$ &,$- 477 * * *$ &,$- 368 * * *$ &,$- 345 * * *$ \\
\hline $\mathrm{ZA}$ &,$- 625 * * *$ &,$- 379 * * *$ &,$- 570 * * *$ &,$- 440 * * *$ &,$- 290 * * *$ &,$- 362 * * *$ \\
\hline $\mathrm{SF}$ &,$- 526 * * *$ &,$- 244 * * *$ &,$- 451 * * *$ &,$- 400 * * *$ &,$- 250 * * *$ &,$- 355 * * *$ \\
\hline SM &,$- 474 * * *$ &,$- 294 * * *$ &,$- 525 * * *$ &,$- 278 * * *$ &,$- 237 * * *$ &,$- 231 * * *$ \\
\hline SO &,$- 604 * * *$ &,$- 250 * * *$ &,$- 457 * * *$ &,$- 530 * * *$ &,$- 344 * * *$ &,$- 360 * * *$ \\
\hline SR &,$- 545 * * *$ &,$- 291 * * *$ &,$- 513 * * *$ &,$- 348 * * *$ &,$- 199 * * *$ &,$- 419 * * *$ \\
\hline SS &,$- 551 * * *$ &,$- 249 * * *$ &,$- 449 * * *$ &,$- 421 * * *$ &,$- 265 * * *$ &,$- 392 * * *$ \\
\hline ZWO & &, $237 * * *$ & & & & \\
\hline ZWZ & &, $157 * *$ & & & & \\
\hline ZWW &, $162 * *$ &, $282 * * *$ &, $151 * *$ & & &, $127 *$ \\
\hline $\mathrm{RO}$ &,$- 284 * * *$ & &,$- 231 * * *$ &,$- 295 * * *$ &,$- 215 * * *$ &,$- 199 * * *$ \\
\hline RO5 &,$- 174 * * *$ & &,$- 147 * *$ &,$- 215 * * *$ & &,$- 169 * *$ \\
\hline $\mathrm{RO} 4$ &, $117 *$ & & &, $167 * *$ & &, $116^{*}$ \\
\hline RO3 &, $228 * * *$ & &, $199 * * *$ &, $203 * * *$ &, $240 * * *$ &, $128^{*}$ \\
\hline $\mathrm{RO} 2$ &, $167 * *$ & &, $177 * * *$ &, $211 * * *$ & &, $167 * *$ \\
\hline RO1 &,$- 341 * * *$ & &,$- 244 * * *$ &,$- 353 * * *$ &,$- 230 * * *$ &,$- 216 * * *$ \\
\hline $\mathrm{T} / \mathrm{F}$ &, $127 *$ & & &, $126^{*}$ &, $234 * * *$ & \\
\hline C.NET & & & & &, $157 * *$ & \\
\hline C.TOT &, $149 * *$ &, $173 * *$ & & &, $156 * *$ & \\
\hline DP &,$- 570 * * *$ &,$- 297 * * *$ &,$- 522 * * *$ &,$- 407 * * *$ &,$- 238 * * *$ &,$- 384 * * *$ \\
\hline GM &,$- 616^{* * *}$ &,$- 335 * * *$ &,$- 540 * * *$ &,$- 425 * * *$ &,$- 295 * * *$ &,$- 405 * * *$ \\
\hline PSY &, $232 * * *$ &, $121^{*}$ &, $143 * *$ &, $147 * *$ &, $122 *$ &, $212 * * *$ \\
\hline PD &,$- 548 * * *$ &,$- 340 * * *$ &,$- 546 * * *$ &,$- 346 * * *$ &,$- 259 * * *$ &,$- 306 * * *$ \\
\hline $\mathrm{N}$ &,$- 665 * * *$ &, $323 * * *$ &,$- 549 * * *$ &,$- 499 * * *$ &,$- 295 * * *$ &,$- 480 * * *$ \\
\hline PI &,$- 157 * *$ &,$- 163 * *$ &,$- 143^{* *}$ & &,$- 108^{*}$ & \\
\hline
\end{tabular}

*** korelacja jest istotna na poziomie 0,001 (dwustronnie)

** korelacja jest istotna na poziomie 0,01 (dwustronnie)

* korelacja jest istotna na poziomie 0,05 (dwustronnie)

Źródło: K. Tomaszek (2010), Podmiotowe uwarunkowania poczucia alienacji u młodzieży, Lublin: Archiwum KUL (niepublikowana rozprawa doktorska), s. 270-280. 
W świetle wyników doświadczanie wyobcowania ściśle wiąże się z licznymi zniekształceniami w obrazie siebie z dominującą deprecjacją własnej osoby w postaci: wzmożonego samokrytycyzmu, niskiej samooceny, trudności w określeniu własnej tożsamości, braku zadowolenia z siebie oraz negatywnej oceny siebie w wymiarach zewnętrznych i wewnętrznych obrazu siebie. Odnotowano następujące prawidłowości:

- im wyższy poziom samokrytycyzmu, tym wyższe wskaźniki ogólnego poziomu wyobcowania, poczucia anomii i bezsensu,

- im niższy poziom samooceny (tj. słabsze wskaźniki określonej tożsamości i mniejsze zadowolenie z siebie, którym towarzyszą nieprawidłowości w zachowaniu), tym wyższe wskaźniki wyalienowania u młodzieży,

- im więcej zniekształceń i nieprawidłowości w zakresie wymiarów zewnętrznych obrazu siebie (,ja” fizyczne, ,ja” moralno-etyczne, ,ja” osobowe, ,ja" rodzinne oraz , ja” społeczne), tym wyższe wskaźniki wyobcowania,

- im mniejsza zwartość wymiarów wewnętrznych obrazu siebie, tym wyższy ogólny poziom wyalienowania oraz wskaźniki poczucia bezsensu i osamotnienia,

- im wyższy poziom anomii, tym mniejsza całkowita zwartość obrazu siebie oraz zwartość wymiarów zewnętrznych i wewnętrznych,

- poczucie alienacji i większość jego wymiarów wiąże się ze zniekształceniami w obrazie siebie (tj. z unikaniem odpowiedzi skrajnych i preferencją do odpowiedzi środkowych). Prawidłowość ta nie odnosi się tylko do poczucia anomii. Wynik ten wskazuje na mniejszą zdolność do kontroli zachowania i tendencję do braku jasności w ocenie siebie, które są obecne u młodzieży wyalienowanej,

- im wyższy poziom samowyobcowania, tym większa skłonność do nadmiernego podkreślania pozytywnych lub negatywnych cech (Konflikt sieciowy). Zwiększa się zatem ilość zniekształceń w obrazie siebie,

- im wyższy poziom globalnego wyalienowania, poczucia anomii i samowyobcowania, tym wyższe wskaźniki wewnętrznego nieładu, sprzeczności i braku zgodności w percepcji siebie (Konflikt całkowity),

- im wyższe wskaźniki wyobcowania, tym wyższy poziom zaburzeń w koncepcji siebie, szczególnie w postaci tendencji do większej obrony pozytywnej, większego ogólnego nieprzystosowania, większego poziomu zaburzeń osobowości i neurotyzmu,

- większy psychotyzm wiąże się z wyższym ogólnym poczuciem alienacji i poczuciem osamotnienia,

- wyższe ogólne poczucie wyalienowania, poczucie anomii, bezsensu i samowyobcowania wiąże się z mniejszą integracją osobowości. 
Szczegółowe badania wykazały, że znaczna liczba wskaźników koncepcji siebie współwystępuje z doświadczaniem wyobcowania. W celu określenia, które zmienne psychologiczne w największym stopniu decydują o pojawieniu się poczucia alienacji, zastosowano metodę krokowej regresji wielokrotnej. Analizę przeprowadzono na wynikach całej grupy badanych adolescentów.

Tab. 6. Udział wskaźników obrazu siebie w wyjaśnianiu ogólnego poziomu poczucia alienacji WOPA w regresji wielokrotnej krokowej

\begin{tabular}{|l|c|c|c|}
\hline \multicolumn{1}{|c|}{ Zmienne niezależne (Wyjaśniające) } & $\beta$ & $\mathrm{t}$ & $\mathrm{p}$ \\
\hline WO & $-0,484$ & $-4,023$ & 0,000 \\
\hline $\mathrm{N}$ & $-0,427$ & $-3,475$ & 0,001 \\
\hline $\begin{array}{l}\text { Współczynnik korelacji wielokrotnej } \mathrm{R}=0,684 \\
\text { Skorygowany współczynnik wielokrotnej determinacji } \mathrm{R}^{2}=0,465 \\
\text { Istotność równania F=12,078; } \mathrm{p}=0,001\end{array}$ & & & \\
\hline
\end{tabular}

Źródło: opracowanie na podstawie badań własnych.

Wyniki równania regresji wskazują, że na całkowity poziom ogólnego wyobcowania w badanej grupie nastolatków mają wpływ dwa wskaźniki obrazu siebie: wynik ogólny obrazu siebie (WO) oraz neurotyzm (N). Parametry równania regresyjnego uprawniają do wniosku, że zmienne te w istotnym stopniu wyznaczają poziom ogólnego wyobcowania $\left(\mathrm{R}^{2}=0,465\right)$.

\section{DYSKUSJA WYNIKÓW}

Przedstawione wyniki analiz statystycznych potwierdzily wszystkie postawione hipotezy badawcze. Doświadczanie wyalienowania przez młodzież wiąże się z poważnymi zniekształceniami w percepcji siebie. Zniekształcenia obrazu siebie u wyalienowanych nastolatków polegają na nadmiernym krytycyzmie, braku akceptacji siebie, mniejszej zwartości struktury obrazu siebie, obecności tendencji sprzecznych w percepcji siebie oraz na skłonności do zafałszowywania opisu własnej osoby. W świetle uzyskanych danych młodzież wyalienowana odznacza się też zaburzeniami w koncepcji siebie, tj. wzmożoną obronnością, wysokim ogólnym nieprzystosowaniem, obecnością defektów i nieprawidłowości osobowości oraz silną tendencją do zachowań neurotycznych.

Powyższe ustalenia potwierdzają wyniki wcześniejszych badań, m.in. K. Tarquin i C. Cook-Cottone (2008), K. Tomaszek (2007) oraz P. Piotrowskiego i K. Zajączkowskiego (1999). Autorzy ci wskazują na negatywną samoocenę i znaczne rozbieżności pomiędzy ,ja realnym” a ,ja idealnym” obecne u osób wyalienowanych. W. Kozłowski (1996) zwraca uwagę na pojawianie się u dorastającej młodzieży samotności (według niego tożsamej z alienacją), której to- 
warzyszy skłonność do „deformacji w spojrzeniu na siebie”. Zgodnie z wynikami analizy regresji czynnikami predestynującymi do doświadczania wyobcowania są niskie poczucie własnej wartości i brak zaufania do siebie (-WO) oraz neurotyzm (-N). Według P. Piotrowskiego i K. Zajączkowskiego (1999) w idealnym obrazie siebie osób wyobcowanych zawarte są charakterystyki, które paraliżują i blokują rozwój. Jednocześnie Mowrer (1965, za: Płużek 1994) podkreśla, że idealny obraz siebie, który jest względnie możliwy do osiągnięcia, chroni człowieka przed ostateczną alienacją. Autorka zauważa, że wyobcowanie człowieka wynika z manipulowania informacjami o sobie dla osiągnięcia osobistych celów. Jednostka wypracowuje wówczas tzw. maski, które zmieniają się w zależności od sytuacji i utrudniają ukształtowanie trwałej tożsamości. Pozorną tożsamość stwarza wówczas obraz idealny, który jest bardziej trwały niż realne ja (Rogers 2002).

Według A. Januszewskiego (1986) podłożem opisanych powyżej nieprawidłowości w kształtowaniu się tożsamości jest „przysposobienie osobiste”. Wynika ono z psychopatycznego sposobu interpretacji i rozwiązywania sytuacji społecznych. W kontaktach społecznych osoby takie tylko pozorują relację symetryczną, faktycznie tworząc ukrytą relację asymetryczną. W konsekwencji traktują innych w sposób instrumentalny. Ujawnione w badaniach wysokie korelacje między wyalienowaniem a neurotycznością potwierdzają powyższy mechanizm. Nastolatki doświadczające wyobcowania prezentują zachowania mające na celu ucieczkę od świata realnego, unikanie podejmowania decyzji i odpowiedzialności za własny los. Narcystyczne odcięcie się od rzeczywistości inspiruje później neurotyka do poszukiwania oparcia w iluzorycznym przystosowaniu osobistym (Freud 1997, 1982).

Powyższa interpretacja jest zgodna z teoretycznym ujęciem źródeł alienacji opisanym przez E. Fromma (1996). Autor ten wskazuje, że człowiek wyobcowany utracił łączność ze swą własną indywidualnością. Według A. Januszewskiego (1986) głównym motywem manipulacji neurotycznej jest mniej uświadomiony motyw silnych niekontrolowanych zachowań obronnych. Neurotyk zafałszowuje obraz innych, projektując na nich własne nieakceptowane cechy, co zakłóca interakcje międzyludzkie. Jednocześnie w świetle badań jedną z głównych charakterystyk osób wyobcowanych jest prezentowanie wrogości względem innych, czemu towarzyszy skłonność do odcinania się od nich w sytuacji pojawienia się zakłóceń w kontaktach (Tomaszek 2009). Poczucie alienacji znacząco zaburza strukturę ,ja", co w efekcie doprowadza do patologii w zachowaniu (Lynch, Convey 1979). Osoby wyobcowane funkcjonują na granicy zdrowia psychicznego i/lub dobrostanu. Powyższy stan jest następstwem obecnej u tych osób destabilizacji systemu regulacyjnego oraz sztywności struktur poznawczych w postaci m.in. błędnej oceny własnych możliwości, potrzeb i aspiracji, trudności w trafnej orientacji w świecie, braku przyswajania norm społecznych i kulturowych 
(Korzeniowski 1991; Otto, Featherman 1975). Cechy te uniemożliwiają prawidłową organizację napływających z otoczenia bodźców. Chaotyczne i nieadekwatne funkcjonowanie $\mathrm{w}$ świecie oraz niski poziom adaptacyjności do warunków otoczenia powodują, że młodzież wyalienowana nie prezentuje takich zachowań, które generują pozytywne wzmocnienia ze strony otoczenia. Jednak młodzież wyobcowana za trudności w relacjach interpersonalnych w największym stopniu obwinia siebie. W dalszej perspektywie powtarzające się porażki doprowadzają do wykształcenia stałej tendencji do niedoceniania własnych zalet i podkreślania wad. Możliwe, że właśnie z tej przyczyny, pomimo nierzadko dużego potencjału intelektualnego, młodzież ta nie osiąga sukcesów szkolnych.

Dotychczasowe badania wskazują na związki poczucia alienacji z takimi zmiennymi osobowościowymi, jak: irracjonalny system sądów, słabe myślenie perspektywiczne, podatność na sugestie, skłonność do myślenia magicznego i życzeniowego, skłonność do autorytaryzmu i sztywności w przejawianych poglądach (Otto, Feartherman 1975; Kmiecik-Baran 1995; Piotrowski 2001; Domeredzka 2002; Niewiadomska 2006). Perspektywa poznawcza wyobcowanych nastolatków jest zawężona do wąskiego ujmowania problemów. Ogranicza ich bowiem lęk przed porażką i konsekwencjami podejmowanych działań, przy tendencji do wybierania zadań nieadekwatnych do własnych szeroko ujmowanych możliwości. Niepowodzenia w sferze intelektualnej doprowadzają do wykluczenia wyalienowanych nastolatków z grupy rówieśniczej, co wtórnie wzmaga napięcie psychiczne. Wyobcowanie wiąże się z poczuciem braku kontroli nad własnym życiem oraz przekonaniem, iż przyczyny trudności są niezmienialne. Taki system sądów wtórnie wpływa na wzrost depresyjności, dezakceptację siebie i pesymistyczne nastawienie odnośnie do przyszłych kontaktów i wydarzeń (Kmiecik-Baran 1995; Nicol 2007).

Badania A. Lewickiej-Zelent i R. Abramciowa (2014) w grupie uczniów szkół muzycznych pokazują, że niska empatia emocjonalno-poznawcza wiąże się z wysokim poczuciem alienacji, samowyobcowania, wyizolowania i osamotnienia. Małe kompetencje emocjonalne, interpersonalne i zaradcze, które cechują wyalienowaną młodzież, sprawiają, że poradzenie sobie z własną izolacją bez pomocy z zewnątrz staje się niemożliwe. Mechanizm ten utrwala się na skutek kolejnych porażek na gruncie szkolnym i towarzyskim. Nakręca to spiralę marginalizacji i niedopasowania młodego człowieka do otoczenia. Odreagowanie wewnętrznych napięć nierzadko przybiera formę zachowań dewiacyjnych, aspołecznych czy autodestruktywnych. 


\section{BIBLIOGRAFIA}

Biegasiewicz M. (2010), Poczucie alienacji a wsparcie społeczne u nieletnich, „Studia Psychologica UKSW", 10.

Brzezińska A. (2006), Dzieciństwo i dorastanie: korzenie tożsamości osobistej i społecznej, [w:] A.W. Brzezińska, A. Hulewska, J. Słomska (red.), Edukacja regionalna, Warszawa: Wydawnictwo Naukowe PWN.

Chlewiński Z. (2000), Religia a osobowość człowieka, [w:] H. Zimoń (red.), Religia w świecie wspótczesnym. Zarys problematyki religiologicznej, Lublin: TN KUL.

Chodkiewicz J., Śmiałkowska M. (2007), Poczucie osamotnienia a wsparcie społeczne i zadowolenie z życia u mężczyzn uzależnionych od alkoholu, „Acta Univesitatis Lodziensis. Folia Psychologica", 11.

Cierpiałkowska L. (2006), Oblicza wspótczesnych uzależnień, Poznań: Wyd. UAM.

Domeredzka A. (2002), Skąd tyle agresji?, „Edukacja i Dialog”, 3.

Erikson E.H. (2002), Dopetniony cykl życia, Poznań: Dom Wydawniczy Rebis.

Freud Z. (1982), Wstęp do psychoanalizy, wyd. 3, Warszawa: Wydawnictwo PWN.

Freud Z. (1997), Poza zasada przyjemności, Warszawa: PWN.

Fromm E. (1996), Zdrowe spoleczeństwo, Warszawa: Państwowy Instytut Wydawniczy.

Giddens A. (2001), Nowoczesność i tożsamość. „Ja” i społeczeństwo w epoce późnej nowoczesności, Warszawa: Wydawnictwo PWN.

Januszewski A. (1986), Funkcje samoakceptacji w poznawaniu siebie i innych ludzi, [w:] A. Biela, C. Walesa (red.), Problemy współczesnej psychologii. Materiaty z I konferencji naukowoszkoleniowej psychologów regionu lubelskiego, Lublin: PTP.

Kmiecik-Baran K. (1995), Poczucie alienacji - destruktywne i konstruktywne sposoby minimalizacji, Gdańsk: Wydawnictwo Uniwersytetu Gdańskiego.

Korzeniowski K. (1991), O psychologicznych przesłankach poczucia podmiotowości-alienacji politycznej, „Przegląd Psychologiczny”, XXXIV, 2.

Kozłowski W. (1996), Samotność i osamotnienie, „Nowa Szkoła”, 5.

Lewicka-Zelent A., Abramciów R. (2014), Empatyczność i poczucie alienacji młodzieży uzdolnionej muzycznie, „Annales Universitatis Paedagogicae Cracoviensis. Studia Psychologica”, VII, Folia 159.

Lynch J.J., Convey W.H. (1979), Loneliness Disease, and Death. Alternative Approaches, "Psychosomatics", 20.

Newman B.M., Newman P.R. (2001), Group Identity and Alienation: Giving the we its Due, "Journal of Youth and Adolescence", 30, 5,

DOI: http://dx.doi.org/10.1080/02673843.2001.9747889.

Nicol A.A.M. (2007), Social Dominance Orientation, Right - Wing Authoritarianism, and their Relation with Alienation and Spheres of Control, "Personality and Individual Differences", 43, DOI: http://dx.doi.org/10.1016/j.paid.2007.02.014.

Niewiadomska I. (2006), Psychospołeczne uwarunkowania alienacji społecznej byłych więźniów, „Zamojskie Studia i Materiały. Pedagogika”, 2 (22).

Otto L.B., Featherman D.L. (1975), Social Structural and Psychological Antecedents of Self-estrangement and Powerlessness, "American Sociological Review", 40,

DOI: http://dx.doi.org/10.2307/2094175.

Piotrowski P. (2001), Zachowania dewiacyjne i aktywność prospołeczna młodzieży a poczucie alienacji, „Szkoła Specjalna”, 1.

Piotrowski P., Zajączkowski K. (1999), Poczucie alienacji chłopców z grupy wysokiego ryzyka. Efektywność oddziaływań profilaktycznych, „Psychologia Wychowawcza”, 5.

Płużek Z. (1994), Psychologia pastoralna, Kraków: Instytut Teologiczny Księży Misjonarzy.

Rogers C.R. (2002), O stawaniu się osobą, Poznań: Dom Wydawniczy Rebis. 
Seeman M. (1959), On the Meaning of Alienation, "American Sociological Review”, 24,

DOI: http://dx.doi.org/10.2307/2088565.

Seemann M. (1975), Alienation Studies, “Annual Review of Sociology”, 1, DOI: http://dx.doi.org/10.1146/annurev.so.01.080175.000515.

Steuden S. (1997), Dynamika zmian osobowości u osób z rozpoznana schizofrenia, Lublin: RW KUL.

Tarquin K., Cook-Cottone C. (2008), Relationships Among Aspects of Student Alienation and Self Concept, "School Psychology Quarterly", 23, 1,

DOI: http://dx.doi.org/10.1037/1045-3830.23.1.16.

Tomaszek K. (2007), Korelaty osobowościowe poczucia alienacji u młodzieży, Lublin: Archiwum KUL (niepublikowana praca magisterska).

Tomaszek K. (2009), Przyczyny poczucia alienacji młodzieży, „Katecheta”, 7-8.

Tomaszek K. (2010), Podmiotowe uwarunkowania poczucia alienacji u młodzieży, Lublin: Archiwum KUL (niepublikowana rozprawa doktorska).

Tomaszek K., Tucholska S. (2012), Psychospołeczne nastęstwa poczucia alienacji u młodzieży, „Paedagogia Christiana”, 2/30.

Uchnast Z. (2007), Tennessee Skala Obrazu Siebie, Lublin: KUL, Katedra Psychologii Ogólnej (mps).

Windle M., Davies P.T. (2003), Teoria rozwojowa i związane z nia badania, [w:] K.E. Leonard, H.T. Blane (red.), Picie i alkoholizm w świetle teorii psychologicznych, Warszawa: PARPA.

Woźniak-Krakowian A., Ortenburger D. (2003), Poczucie alienacji młodzieży i jej konsekwencje, „Tolerancja”, 10.

Zawadzki P. (2007), Poczucie alienacji, samotności i depresji u współczesnej młodzieży, „Wychowanie na co Dzień", 12.

\section{SUMMARY}

This study investigated the relationships between student alienation and the self concept. Adolescents completed The Kmiecik-Baran Scale measured Sense of Alienation and the Tennessee Self Concept Scale (TSCS). Analysis was based on total of 331 undergraduate students age 16-20 years. Results indicated a moderate negative correlation between most subscales of TSCS and student alienation. Alienation correlates with low self concept, lower feelings of self - worth, higher selfcriticism, problems with self-identity, negative self - satisfaction. Student Alienation also correlates with Defensive Positive, General Maladjustment, Psychosis, Personality Disorder, Neurosis. A stepwise multiple regression analysis indicated that two variables of self - concept best predicted the state of being alienated. The Total Positive and Neurosis accounted for a significant portion $\left(\mathrm{R}^{2}=0,465\right)$ of the variance in Total Student Alienation.

Keywords: alienation; isolation; self concept; identity disorder 